\title{
Evaluating Methods of Composting on Date of Maturity and Quality of Compost in Assosa, Western Ethiopia
}

Biruk Teshome ${ }^{1 *}$ and Jabir Amza ${ }^{2}$

Department of Plant Science, Assosa University, Assosa, Ethiopia

\begin{abstract}
Organic matter addition to degraded soils is one best option in reclaiming soil productivity; and in relation to this the habit of preparing organic fertilizers (composting) using the best available method, which could simplify preparation and conserve the quality of compost is necessary. Therefore this study was conducted with the objective of evaluating different methods of composting in terms of date of compost maturity and selected chemical and physical property of the compost. The treatments were rotating bin, turned heap, turned pit, bamboo layered heap and non-turned pit methods, which were replicated three times using a complete randomized design. The analysis of variance showed, there was significant $(p<0.01)$ difference among methods in the date of maturity, organic carbon, total nitrogen, exchangeable calcium (Ca), exchangeable potassium $(\mathrm{K})$ and dry bulk density. The rotating bin method showed relatively shorter period of compost maturity date (37.67 days), followed by turned pit (62.33) and turned heap (62.67 days) methods. The methods showed no significant difference in compost temperature, while showing the highest mean temperature $\left(52.40^{\circ} \mathrm{C}\right)$ on the fourth day for all the methods. The $\mathrm{pH}(7.13)$, organic carbon $(32.67 \%)$ and total nitrogen $(2.8 \%)$ of rotating bin compost were significantly higher than all the methods, followed by bamboo layered method. The amount of $\mathrm{Ca}$ and potassium $\mathrm{K}$ were also highest for the rotating bin composting, but with the least dry bulk density. Generally, frequent turning of compost as in the case of rotating bin facilitated suitable temperature (mesophilic) for longer period until the curing phase, while reducing the loss of carbon $\left(\mathrm{CO}_{2}\right)$ and nitrogen $\left(\mathrm{NH}_{3}{ }^{+}\right)$through reducing anaerobic decomposition, it also conserved leaching of nutrients $\left(\mathrm{Ca}^{+2}, \mathrm{~K}^{+}\right)$and reduced the date of maturity with a least cost of preparation.
\end{abstract}

Keywords: Composting methods; Compost quality; Compost maturity

\section{Introduction}

Sustainable crop production system is calling our attention for the national agriculture of Ethiopia; because of soil degradation (loss of soil fertility) caused by sever soil loss and unbalanced crop and livestock production of the arable lands [1]. In sustainable and integrated crop production systems the inclusion of compost proved to have significant effect on quantity and quality of crop productions [2,3]. Irrespective of its importance in integrated soil fertility management, compost utilization among farmers in Ethiopia is very limited. Farmers are aware of the benefits that could be obtained from use of composts, but they don't have a simple to use and health method of composting [4], which accompanied by seasonal agricultural activities burdens them to use the conventional method of composting.

Composting is a method of enhancing natural decomposition process, through balanced carbon to nitrogen ratio $(\mathrm{C}: \mathrm{N})$ of raw organic materials that should be supplied with adequate moisture and oxygen to intensify the activity of decomposing microorganisms [4]. Composting process requires some facilities and knowledge on the decomposing organic materials such the $\mathrm{C}: \mathrm{N}$ ratio to properly mix a desirable proportion of organic materials in the compost pile [4]. In the compost pile mixes when the C:N ratio goes higher or lower the composting process will be hindered or may be stopped at all [5]. It is very important to keep the $\mathrm{C}: \mathrm{N}$ of the compost pile in the range between 25:1 and 35:1. However, C:N higher than 35 would lower multiplication of decomposing microorganisms due to shortage of $\mathrm{N}$ to synthesis their body protein. And C:N lower than 25 result in production of high amount of ammonia by microorganisms, which also cause lower $\mathrm{pH}$, reduced decomposition and unpleasant odour of the compost [6].

The C:N of some organic materials can be referred from studies reviewed on different sources, for instance [7] described sawdust to have the highest C:N next to newspapers (511:1) with a bulk density of $417 \mathrm{~kg} \mathrm{~m}^{-3}$, straw have $80: 1$ with a bulk density of $80 \mathrm{~kg} \mathrm{~m}^{-3}$, corn silage have $44: 1$ with a bulk density of $688 \mathrm{~kg} \mathrm{~m}^{-3}$, horse manure have $30: 1$ with a bulk density of $592 \mathrm{~kg} \mathrm{~m}^{-3}$ and poultry litter have $15: 1$ with a bulk density of $320 \mathrm{~kg} \mathrm{~m}^{-3}$. Based on this ratio the organic materials can be properly mixed to the $\mathrm{C}: \mathrm{N}$ ratio desired between 1:25 and 1:30 using method developed by [8].

Monitoring and controlling the moisture content, oxygen level and temperature of the composting process is also another important issue to have good quality and large quantity compost within scheduled time desired [4]. On the other hand type of raw materials, their proportions in the pile and the methods of composting significantly affect the controllability of composting (rate of decomposition) and the quality of the compost. To have a controlled composting process and good quality compost the choice of composting methods is crucial. The quality of compost is determined by the nutrient composition, concentration of heavy metals, presence of inert materials, inclusion of weed seeds, pathogenic bacteria and compost maturity [9]. Thus, a good quality compost will have a dark brown colour and maturity index (ammonia to nitrate $\left(\mathrm{NH}_{3}: \mathrm{NO}_{3}\right)$ and $\left.\mathrm{C}: \mathrm{N}\right)$ ratio in the range of 0.5 to 3 and less than 25, respectively [10]; while having less concentrations of heavy metals, weed seeds and pathogenic bacteria [9].

*Corresponding author: Teshome B, Department of Plant Science, Assosa University, P.O. Box 18, Assosa, Ethiopia, Tel: +251-985238877; E-mail: kirubtsh@gmail.com

Received October 14, 2017; Accepted October 25, 2017; Published November 01,2017

Citation: Teshome B, Amza J (2017) Evaluating Methods of Composting on Date of Maturity and Quality of Compost in Assosa, Western Ethiopia. Int J Waste Resour 7: 310. doi: 10.4172/2252-5211.1000310

Copyright: (C) 2017 Teshome B, et al. This is an open-access article distributed under the terms of the Creative Commons Attribution License, which permits unrestricted use, distribution, and reproduction in any medium, provided the original author and source are credited. 
Depending on the type of organic materials used and method of composting, the nutrient delivering capacity as well as soil amending property of compost could vary. Compost prepared from much of green organic materials that is rich in nitrogen will result in acidity (low $\mathrm{pH}$ ) of the compost, which might increase the total acidity of the soil after application $[11,12]$. However, compost made from balanced organic materials and materials that contain elements like $\mathrm{Ca}$ will result in neutral to alkaline compost (high $\mathrm{pH}$ ), which could reduce soil acidity $[11,12]$.

Methods of composting are of different types, but they can be categorized in to two major classes, as traditional and rapid method of composting, where: Indore composting (heap and pit), Bangalore (heap and pit), trench and windrows methods of composting are considered as traditional [13]. And invessel (digester composting), bin composting, vermicomposting and EM composting are considered as rapid composting methods [14]. Some composting methods have passive aeration mechanisms that allow the entry of oxygen (air) in to the pile, while some others have active aeration mechanism or simplified in-vessel turning method to allow entry of air, and the rest methods are turned manually to facilitate aeration $[11,12]$.

In Ethiopia only two traditional methods of composting the Indoor and Bangalore methods are used by some innovative farmers at small holding farmer's scale, while the majority of farmer are pushing it aside due to its high labour requirement (additional task) and risk of health, while some other farmers resorted to the anaerobic composting [13]. Thus, this research tried to evaluate, various composting methods some of which are not commonly in use among farmers in Ethiopia, such as the rotating bin (compost tumbler). This method of composting is known as rapid composting systems that will have certain important advantages over the traditional composting systems mainly in time of decomposition, nutrient content, reduction in phytopathogens and weed seeds [11]. A comparative study by Bera et al. [15] showed lower contents of organic carbon and total $\mathrm{N}$ due to passively aerated (Indigenous) method of composting, while compost prepared through biodynamic and novo composting methods showed higher organic carbon, total $\mathrm{N}$ and nutrient contents. Harrison et al. [16] also reported higher organic carbon and nitrogen contents for methods of composting that facilitated entry of oxygen either through frequent turning or passively aerated mechanism, due to reduced emission of methane and volatilization of ammonia. Therefore this study was conducted with the major objective of evaluating different composting method on the date of compost maturity and nutrient contents of compost.

\section{Materials and Methods}

\section{Description of the study site}

The experiment was conducted during rain free seasons of 2015, in the Assosa University, which is located in Benishangul Gumuz region, western Ethiopia. The study site is situated at an altitude of 1550 meters, with longitude and latitude of $34^{\circ} 34^{\prime} 15.4^{\prime \prime} \mathrm{E}$ and $10^{\circ} 227.6^{\prime \prime} \mathrm{N}$, respectively. It is approximately $660 \mathrm{~km}$ west of the capital, Addis Ababa. The rainfall usually occurs between April and October; and in 2015 it occurred between March and October with mean annual rainfall of $667.2 \mathrm{~mm}$. The minimum and maximum mean annual temperatures of the area are $16.7^{\circ} \mathrm{C}$ and $27.9^{\circ} \mathrm{C}$, respectively; and in the year 2015 these were, 15.9 and $28.6^{\circ} \mathrm{C}$, respectively.

\section{Raw materials, treatments and experimental design}

Various locally available organic materials were combined and assumed as one source of composting materials for all methods of composting. The organic materials used were: sorghum leaves and stalks, kitchen scraps, tree leaves, broad leaved weeds, grass weeds, livestock manure and saw dust. The treatments were: 1 . Static pit composting (control), 2. Turned pit composting, 3. Rotating bin (Tumbler composting) 4. Bamboo layered heap composting, and 5. Turned heap composting, which were replicated three times and laid out in completely randomized design (CRD). The dimensions of pit and heap methods were based on the descriptions [14]; while the dimensions of the rotating bin were made based on the description [17]

\section{Experimental procedures}

A site suitable for all methods of composting that was accessible to water sources, well drained and with sufficient sunshine per day was selected for the composting process. The raw materials were chopped at approximately 5 to $7 \mathrm{~cm}$ length. For all composting methods similar organic raw materials in precise equal C:N ratio were layered (piled) to satisfy a C:N ratio of 25:1 by method [18]. After piling the raw organic materials, the composting process was initiated; and all the necessary management activities like watering and turning were undertaken.

The turning process was made based on pre-determined turning frequencies for each method; the rotating bin was turned every two days after the first week of no turning period, the pit and heap methods were turned every three weeks, while the bamboo and non-turned pit were not turned at all. During the composting process the temperature of the compost were recorded every two days. The composting process was regularly monitored and sufficient amount of water was applied on time according to the need for each method. The phases or stages of composting process were estimated based on the changes in temperature and visual observations. Maturity of the compost was estimated by colour and texture changes observed. When the compost was assumed well matured, the compost prepared by each methods were mixed, homogenised and samples were taken from six positions of the pile and samples composited. The samples were then taken to the laboratory and analysed for compost maturity, selected chemical property and bulk density of the compost.

\section{Data collected}

During the composting process the temperature of the compost was recorded regularly at 2 days interval for the first 30 days. The date of compost maturity was recorded when the compost assumed a dark brown colour following their curing phase and confirmed by maturity index. Literally compost that have maturity index (ammonia to nitrate ratio between 0.5-3 and carbon to nitrogen ratio of less than 25 is considered as well matured compost). The samples taken were analysed for maturity index, compost dry bulk density; and selected chemical properties using the standard laboratory procedures.

Percent organic carbon content (OC\%) was determined following the method of potassium dichromate oxidation [18], $\mathrm{pH}$ (water extracted paste) by potentiometric analysis [19], electrical conductivity (EC) (water extracted paste) by conductometric analysis [20], moisture content by oven dry methods. Total $\mathrm{N}$ was determined by Kjeldahal digestion method [19], nitrate nitrogen was determined by indirect measurements of Kjeldahal digest [21]; $\mathrm{Ca}$ and $\mathrm{Mg}$ by $1 \mathrm{~N}$ ammonium acetate, EDTA (Ethylene diamine tetraacetic acid) method, and $\mathrm{K}$ and Na by $1 \mathrm{~N}$ ammonium acetate extract using flame photometer method. The $\mathrm{C}$ to $\mathrm{N}$ ratio was calculated from the total organic carbon and total nitrogen (sum of total organic N, ammonia and nitrate) [22]. 
Citation: Teshome B, Amza J (2017) Evaluating Methods of Composting on Date of Maturity and Quality of Compost in Assosa, Western Ethiopia. Int J Waste Resour 7: 310. doi: 10.4172/2252-5211.1000310

Page 3 of 6

\section{Statistical analysis}

Analysis of variance (ANOVA) was used to identify whether there was significant difference among treatments and LSD was used in mean separation test, using SAS statistical software version 9 [23].

\section{Results}

\section{Temperature and date of compost maturity}

The mean temperature of methods of composting showed no significant $(p>0.05)$ difference among each other, however the temperature in the intervals (phases) showed significant $(\mathrm{p}<0.01)$ difference (Tables 1 and 2). The temperature taken at the $4^{\text {th }}$ and $2^{\text {nd }}$ days were significantly higher than all temperature measurements, without significant difference to each other (Table 2). The mean highest temperature in the fourth day was $52.40^{\circ} \mathrm{C}$, which possibly represented thermophilic phase of decomposition for all the methods.

Methods of composting showed significant $(\mathrm{p}<0.01)$ difference on the date of compost maturity. The date of maturity ranged between 35 to 90 days depending on the type of composting methods used. The composting bin method (compost tumbler) showed highly significant difference to all methods of composting, reducing the dates of maturity to 37 days. Turned pit and turned heap methods showed no significant difference to each other (62 days), while the two showed significant difference to bamboo layered and non turned pit composting methods (87 days) (Table 1$)$.

\section{Maturity index of the compost}

The ammonia to nitrate ratio showed significant $(\mathrm{p}<0.01)$ difference among the five methods of composting (Table 1). Where, bamboo layered heap and the rotating bin composting methods showed the least ammonia to nitrate ratio (1.89:1), which was in the critical range of value for mature compost; however turned pit, turned heap and nonturned heap methods showed higher ammonia to nitrate ratio which was out of the critical range of compost maturity index value, which might indicate these methods might need more decomposition time for better maturation. The carbon to nitrogen ratio was not significantly ( $p>0.05$ ) different due to methods of composting, but all the methods showed a C:N of less than 25 (Table 1).

\section{Chemical and physical properties of the compost}

Organic carbon content of compost made by rotating bin method showed highly significant $(\mathrm{p}<0.01)$ difference than all composting methods, while bamboo layered heap composting was significantly higher than turned pit method (Table 3 ). The rotating bin method showed the highest OC (32.47\%) having approximately $10 \%$ greater OC than the rest methods together, but turned pit method showed the least OC (Table 3 ).

The release in carbon during decomposition of compost was higher by methods that are turned and tightly covered during the composting process, with carbon release sequence of turned pit $>$ non turned pit $>$ turned heap $>$ heap bamboo $>$ rotating bin. The total nitrogen also showed the same trend as the organic carbon where the rotating bin method was significantly $(\mathrm{p}<0.01)$ higher than the other methods of composting, with the highest total nitrogen of $2.8 \%$, while turned pit method showed the least total nitrogen of $1.52 \%$ (Table 3 )

The calcium (Ca) content of the compost showed significant $(\mathrm{p}<0.01)$ difference among methods of composting. The bin composting method showed the highest calcium content $\left(18.47 \mathrm{cmolc} \mathrm{kg}^{-1}\right)$ with significant difference to all methods of composting (Table 3). The potassium content of the compost also showed the same trend as the calcium. The rotating bin method gave the highest potassium content $(7.37 \mathrm{cmolc}$ $\mathrm{kg}^{-1}$ ) with significant difference to all methods of composting (Table 3).

\begin{tabular}{|c|c|c|c|c|}
\hline Composting methods & Temperature $\left({ }^{\circ} \mathrm{C}\right)$ & Ammonia: Nitrate ratio & Carbon: Nitrogen ratio & Maturity date \\
\hline Rotating bin & $32.00^{\mathrm{a}}$ & $1.89^{\mathrm{b}}$ & $11.60^{\mathrm{a}}$ & $37.67^{c}$ \\
\hline Turned pit & $29.87^{\mathrm{a}}$ & $4.17^{a}$ & $12.63^{\mathrm{a}}$ & $62.33^{b}$ \\
\hline Turned heap & $30.60^{\mathrm{a}}$ & $4.00^{\mathrm{a}}$ & $11.43^{\mathrm{a}}$ & $62.67^{b}$ \\
\hline Bamboo layered heap & $26.67^{\mathrm{a}}$ & $1.89^{b}$ & $10.76^{a}$ & $87.33^{a}$ \\
\hline Non turned pit & $28.27^{\mathrm{a}}$ & $5.22^{\mathrm{a}}$ & $11.02^{\mathrm{a}}$ & $87.67^{a}$ \\
\hline LSD & ns & $1.65^{\star *}$ & ns & $4.58^{* * *}$ \\
\hline CV (\%) & 20.87 & 26.40 & 11.29 & 3.73 \\
\hline
\end{tabular}

Note: Columns followed by same letters are not significantly different using LSD mean separation test

Table 1: The mean temperature, maturity date and indexes of the five methods.

\begin{tabular}{|c|c|c|c|c|c|c|c|c|c|c|c|c|c|c|c|}
\hline Days & 2 & 4 & 6 & 8 & 10 & 12 & 14 & 16 & 18 & 20 & 22 & 24 & 26 & 28 & 30 \\
\hline $\mathrm{T}\left({ }^{\circ} \mathrm{C}\right)$ & $47.40^{\mathrm{a}}$ & $52.40^{\mathrm{a}}$ & $33.60^{b}$ & $25.60^{c}$ & $26.60^{\mathrm{bc}}$ & $26.60^{\mathrm{bc}}$ & $26.60^{\mathrm{bc}}$ & $26.60^{\mathrm{bc}}$ & $26.60^{\mathrm{bc}}$ & $26.60^{\mathrm{bc}}$ & $28.00^{\mathrm{bc}}$ & $26.40^{\mathrm{bc}}$ & $26.40^{\mathrm{bc}}$ & $26.40^{\mathrm{bc}}$ & $26.40^{\mathrm{bc}}$ \\
\hline LSD & \multicolumn{2}{|c|}{$7.92^{* * *}$} & & & & & & & & & & & & & \\
\hline CV (\%) & \multicolumn{2}{|c|}{20.87} & & & & & & & & & & & & & \\
\hline
\end{tabular}

Note: Mean values followed by same letters are not significantly different; and T stands to Temperature

Table 2: The mean temperature of all the methods at two day intervals for 30 days.

\begin{tabular}{|c|c|c|c|c|c|c|c|}
\hline Composting methods & pH & OC (\%) & TN (\%) & $\mathrm{Ca}$ & Mg & $\mathbf{K}$ & $\mathrm{Na}$ \\
\hline Rotating bin & $7.57^{a}$ & $32.47^{\mathrm{a}}$ & $2.80^{\mathrm{a}}$ & $18.47^{a}$ & $14.80^{\mathrm{a}}$ & $7.37^{a}$ & $5.73^{a}$ \\
\hline Turned pit & $7.13^{b}$ & $19.00^{c}$ & $1.53^{c}$ & $13.80^{\mathrm{b}}$ & $13.40^{\mathrm{a}}$ & $5.70^{\mathrm{b}}$ & $4.43^{\mathrm{a}}$ \\
\hline Turned heap & $7.27^{\mathrm{b}}$ & $21.00^{\text {bc }}$ & $1.83^{\mathrm{bc}}$ & $15.07^{b}$ & $14.07^{a}$ & $5.27^{b}$ & $3.83^{a}$ \\
\hline Bamboo layered heap & $7.30^{\mathrm{b}}$ & $24.00^{b}$ & $2.23^{b}$ & $14.57^{\mathrm{b}}$ & $13.67^{a}$ & $5.93^{b}$ & $4.60^{\mathrm{a}}$ \\
\hline Non turned pit & $7.17^{\mathrm{b}}$ & $20.00^{\text {bc }}$ & $1.83^{\mathrm{bc}}$ & $12.57^{\mathrm{b}}$ & $13.00^{\mathrm{a}}$ & $5.17^{\mathrm{b}}$ & $4.17^{\mathrm{a}}$ \\
\hline LSD & $0.25^{*}$ & $4.63^{\text {*t* }}$ & $0.46^{* * *+}$ & $2.44^{* *}$ & ns & $1.09^{* *}$ & ns \\
\hline CV (\%) & 1.88 & 10.94 & 12.42 & 9.02 & 7.92 & 10.20 & 18.79 \\
\hline
\end{tabular}

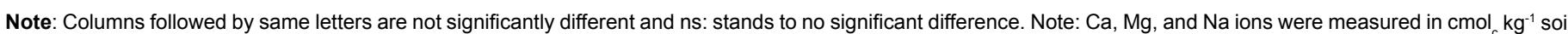
Table 3: chemical properties of the compost prepared by five different methods. 
But $\mathrm{Mg}$ and Na contents of the compost were not significantly ( $\mathrm{p}>0.05)$ different for methods of composting.

The $\mathrm{pH}$ of the compost showed significant $(\mathrm{p}<0.05)$ difference among methods of composting. The rotating bin method showed the highest $\mathrm{pH}$ record of 7.57 with highly significant difference to all methods of composting. The other methods of composting showed compost with a $\mathrm{pH}$ of near neutrality (7.0) without significant difference to each other (Table 3 ).

There was significant $(\mathrm{p}<0.01)$ difference in the dry bulk density of compost among methods of composting (Table 4). The rotating bin (tumbler) method showed the least dry bulk density $\left(0.38 \mathrm{~g} \mathrm{~cm}^{-3}\right)$, while the bamboo and turned heap methods showed significantly lower dry bulk density compared to the non turned and turned pit methods (Table $4)$. There was also significant $(\mathrm{p}<0.01)$ difference in moisture content of the compost among methods composting. The rotating bin, bamboo layered and turned heap showed significantly higher moisture content than the turned pit and non-turned pit methods, without significant difference to each other (Table 4). The bin composting method showed about $37.67 \%$ moisture content of compost at time of harvesting, while turned pit method showed the least moisture content of $14.23 \%$ at time of harvesting (Table 4).

There was significant $(\mathrm{p}<0.01)$ difference among methods of composting on the costs of compost preparation. The least cost was observed for non-turned pit, rotating bin and bamboo layered heap, consecutively without significant difference among them (Table 5); turned pit was with the highest cost followed by the turned heap.

\section{Discussion}

The date of maturity for the five methods of composting varied, owing to provision of suitable temperature, air and moisture, which might have changed the rate of decomposition at different phases of decomposition. Rotating bin method showed the least date compost maturity (37 days) due to its simplified turning mechanism that

\begin{tabular}{|c|c|c|}
\hline $\begin{array}{c}\text { Methods of } \\
\text { composting }\end{array}$ & Dry bulk density $\mathbf{( g ~ c m}^{-3} \mathbf{)}$ & Moisture content (\%) \\
\hline Rotating bin (tumbler) & $0.38^{\mathrm{c}}$ & $36.70^{\mathrm{a}}$ \\
\hline Turned pit & $0.54^{\mathrm{b}}$ & $14.23^{\mathrm{b}}$ \\
\hline Turned heap & $0.40^{\mathrm{c}}$ & $33.73^{\mathrm{a}}$ \\
\hline Bamboo layered heap & $0.41^{\mathrm{c}}$ & $30.07^{\mathrm{a}}$ \\
\hline Non turned pit & $0.67^{\mathrm{a}}$ & $15.57^{\mathrm{b}}$ \\
\hline LSD & $0.07^{\text {***}}$ & $8.96^{\text {***}}$ \\
\hline CV (\%) & 7.82 & 18.91 \\
\hline
\end{tabular}

Note: Columns followed by same letters are not significantly different and ns: stands to no significant difference

Table 4: The dry bulk density and moisture content of the compost at time of harvesting.

\begin{tabular}{|c|c|}
\hline Composting methods & Total variable cost (ETB) \\
\hline Rotating bin (Tumbler) ${ }^{*}$ & $651.67^{c}$ \\
\hline Turned pit & $1058.89^{a}$ \\
\hline Turned heap & $865.56^{\mathrm{b}}$ \\
\hline Bamboo layered heap & $701.11^{c}$ \\
\hline Non turned pit & $643.89^{c}$ \\
\hline LSD & $82.39^{* * *}$ \\
\hline CV (\%) & 5.77 \\
\hline
\end{tabular}

Note: 'The cost of establishment of the rotating bin was not included, only the variable costs of compost preparation were considered for all methods. Note: ETB; stands to Ethiopian birr

Table 5: Total variable cost of methods of composting for producing $100 \mathrm{~kg}$ compost. allowed frequent turning. Thus, the maturity date varied due to turning frequency of the methods, which in turn facilitated the necessary temperature, oxygen and reduced time of anaerobic decomposition. In support to this result [16] used different composting facilities and showed frequent turning of organic materials enhanced the breakdown of large particles, faster maturity and homogenized pile with fast stabilized compost.

For all methods of composting the highest temperature was observed on the fourth day of the compost piling $\left(52.40^{\circ} \mathrm{C}\right)$ (thermophilic phase), after the eighth day the temperature dropped, however the mean temperature of all the methods were found in the range between 26 to $33^{\circ} \mathrm{C}$ which might imply the longest time of composting was spent on mesophilic temperature (Table 1). Since the composting methods were not significantly different on the compost temperature, the mesophilic phase of decomposition was obscured when all composing methods were analysed together. The absence of significant difference among methods composting in temperature might be due to exhibition of similar change in temperature of four methods, which took longer and similar phases of decomposition, while the rotating bin method completed its decomposition within 30 days. And the low temperature during no turning period of the four methods might have been balanced by the curing phase of the rotating bin. Augustin and Rahman [24] showed composting process begins at mesophilic temperature and increases to thermophilic temperature of about $65^{\circ} \mathrm{C}$, which then decrease to mesophilic temperature of between 30 to $40^{\circ} \mathrm{C}$ before every turning of compost and rise to thermophilic temperature after every turning and finally cool down to low temperature of curing until maturity.

The $\mathrm{pH}$ of the compost were nearly neutral for all composting methods with the exception of rotating bin, which showed alkaline $\mathrm{pH}$ (7.57) probably due to well maturity and curing of the compost compared to the other method. A study by Wu et al. [25] showed that $\mathrm{pH}$ of a compost increased during the curing phase of composting than during decomposition period, while time of curing and efficiency of the composting methods might also cause significant variability in the $\mathrm{pH}$ of compost. The maturity index of compost also reflect similar trend as the $\mathrm{pH}$ that compost made using the rotating bin was well matured and cured, since the maturity index (ammonia to nitrate ratio) (1.87) was in the critical range between 0.5 and $3 \mathrm{mg} \mathrm{kg}^{-1}$ and carbon to nitrogen ratio of less than 25 [10]. The near neutrality nature of the compost might be due the type of materials used (fresh green) and possibly due to absence of ash from the materials. In support to this result, Amlinger et al. [11] reported, lower $\mathrm{pH}$ of compost when the compost was prepared from much of green organic materials that are rich in nitrogen. In addition to the $\mathrm{pH}$, the contents of basic cations of the compost $(\mathrm{Ca}, \mathrm{K})$ were lower most likely due to missing ash among the materials used.

The carbon content of compost for the rotating bin was higher than the other methods, which might be due to reduced release of carbon that was related to frequent turning, improved aeration and minimized anaerobic decomposition. While the bamboo layered composting had passive aeration mechanism through the bamboo hole, which facilitated aerobic decomposition and decreased release organic carbon compared to turned pit method. In agreement to this result $[6,16]$ higher organic carbon and nitrogen contents of compost for methods of composting that facilitate entry of oxygen either through frequent turning or passively aerated mechanism, due to reduced emission of methane and volatilization of ammonia. Since rotating bin method and the bamboo layered methods were frequent turned and passively aerated, respectively, they might have contributed in better 
sequestration of organic carbon, which could be higher under more controlled conditions.

The content of nitrogen in compost showed the same trend as the organic carbon, which might relate to the proportional consumption of nitrogen by decomposing microorganism in relation to the consumption of carbon as the carbon to nitrogen ratio determines the rate of decomposition and the consumption of either more of carbon or more of nitrogen. Therefore, the rotating bin method might have also prevented volatilization of ammonia through minimized anaerobic decomposition compared to the methods that partly involved anaerobic decomposition [16].

The difference in the compost chemical contents of $\mathrm{K}$ and Ca could be due to leaching of these ions to the soil particularly for the methods that were in direct contact with the soil, while the rotating bin reduces the spell and leak of compost solutions at time of watering and turning. In support to this result Varma [26] reported, leaching of nutrients including $\mathrm{N}, \mathrm{P}$ and $\mathrm{K}$ from compost pile and composting drum and the leachate loss from drum composting method was the least compared to pile composing methods. On the other hand it could be due to decomposition state of the compost as a result of the different methods, since highly decomposed and stabilized compost contains high amount of potassium [27].

The lower dry bulk density for rotating bin and bamboo composting methods might be due to higher contents of organic carbon and nitrogen making the compost to have a fluffy texture enabling the compost to hold more amount of moisture, which was observed by the moisture content of the composts at time of harvesting. Consistent to this result SAS [25] showed higher water holding capacity of compost made from sawdust prepared in vessel system compared to food and yard waste, animal manure and wood chip compost made in forced air windrow system.

The non-turned pit, rotating bin and bamboo layered composting methods were with the least cost compost preparation, due to absence of the cost of turning for the non-turned pit and bamboo layered compost, while the cost of turning for rotating bin was very low as turning was easy and can be handled by the opportunity cost of the owner. However the total cost was relatively high for all methods of composting, which might arose from the need to control the composting process for the study purpose.

\section{Conclusion}

Methods of composting have showed significant difference in maturity index, days to maturity, $\mathrm{pH}$, organic carbon, total $\mathrm{N}$ and bulk density of compost. Among the methods evaluated the rotating bin composting showed early maturity exceeding the other methods in more than 30 days. The maturity index of the compost for the rotating bin and bamboo layered compost showed well maturity and stable compost. Frequent turning of compost was the major factor which enhanced the rate of decomposition and reduced time of maturity. The bin composting method, turned heap and turned pit methods showed relatively fast maturity dates. The changes in temperature between intervals were more important than the mean temperature of the composting methods. Composting methods that were not turned and those with long gap between two turning showed lower mean compost temperature, which might have resulted in anaerobic decomposing, insufficient maturity and with low nutrient contents. The $\mathrm{pH}$, organic carbon and total nitrogen of the compost were higher for rotating bin and bamboo layered methods compared to the others. These methods were able to reduce the release of carbon and volatilization of ammonia due to better aeration through frequent turning and passively through bamboo holes, respectively. The calcium and potassium content of rotating bin method significantly exceeded the methods that were in direct contact with the soil and liable to leaching (compost leachate), while rotating bin method reduced it. The rotating bin method, bamboo layered and turned heap methods showed low dry bulk density; as they have increased organic carbon and nitrogen contents. Since the rotating bin composting method showed faster maturity, low bulk density and higher nutrient contents with minimal preparation cost, it might be helpful method for preparing compost for farming community in the area.

\section{Acknowledgment}

I am highly indebted to staff members of plant sciences and natural resources in the Assosa University, for their constructive comments during proposal defence. It is of great importance to thank Mr. Damtew Mekonen and staff members of the Assosa soil and plant analysis laboratory for their highly valued support in matters pertaining to compost analysis. My special word of thanks goes to the Assosa University for funding the research execution financially.

\section{References}

1. Gashaw T, Bantider A, Gebresilassie H (2014) Land degradation in Ethiopia: Causes, impacts and rehabilitation techniques. J Environ Earth Sci 4: 98-104.

2. Våje $P(2007)$ Soil fertility issues in the blue nile valley, Ethiopia. In: Bationo A, Waswa B, Kihara J, Kimetu J (eds.), Advances in integrated soil fertility managment in Sub-Saharan Africa: Chanllenges and opportunities. Springer, Netherland.

3. Ganjali H, Mobasser H, Esmaielzehi A, Tavassoli A (2013) Effect of organic compost on yield and protien content of corn cultivars in Khash region. Journal of Novel Applied Sciences 2: 369-374.

4. Rader H (2013) The compost heap: Basic composting in Alaska. University of Alaska Fairbanks, Alaska.

5. Chen L, Marti Md, Moore A, Falen C (2011) The composting process: Dairy compost production and use in Idaho.

6. Marta A, Raviv M (2016) Microbiology of the composting process. In: Van der Wurff A, Fuchs J, Raviv M, Termorshuizen A (eds.), Handbook for composting and compost use in organic horticluture. COST, Wageningen.

7. Dam A, Nibbelink B, Ward D (2009) Windrow composting of poultry carcasses Ministry of Agriculture, Food and Rural Affairs, Ontario.

8. Richard T (2005) NMORO-Compost-Mixes.

9. Brinton WF (2000) Compost quality standards and guidelines: an international view. Woods End Research Laboratory Inc, New York.

10. Woods End Laborarories (2013) Laboratory test interpretation. Journal of Woods End Laboratories 10: 1-7.

11. Amlinger F, Peyr S, Geszti J, Dreher P, Weinfurtner K, et al. (2007) Beneficia effects of compost application on fertility and productivity of soils. Federa Ministry for Agriculture and Forestry, Environment and Water Management, Austria.

12. Christian A, Evanylo G, Pease J (2009) On-farm composting: A guide to principles, planning and operations. Virginia Cooperative Extension, VirginiaTech, Virginia State University, Petersburg.

13. Edwards S, Araya H (2010) How to make and use compost. Food and Agricultural Organization of the United Nations, Rome.

14. Inckel M, De Smet P, Tersmette T, Veldkamp T (2005) The preparation and use of compost. Agromisa Foundation, Wageningen.

15. Bera R, Datta A, Bose S, Dolui A, Chatterjee A, et al. (2013) Comparative evaluation of compost qulity, process convenience and cost under different composting methods to assess their lage scale adoptability potential as also complemented by compost qulity index. Int J Sci Res Pub 3: 1-11.

16. Harrison E, Bonhotal J, Schwarz M (2004) Improving and maintaining compost quality. Compost fact sheet series 2004/2005. Cornell Cooperative Extension, Cornell.

17. Bradford A, McGregor D, Simon D (2003) Container composting in Periurban Kumasi, Ghana. UA-Magazine. 
Citation: Teshome B, Amza J (2017) Evaluating Methods of Composting on Date of Maturity and Quality of Compost in Assosa, Western Ethiopia. Int J Waste Resour 7: 310. doi: 10.4172/2252-5211.1000310

Page 6 of 6

18. Walkley A (2003) Critical examination of rapid method for determining organic carbon in soils: Effect of variation in digestion conditions and of organic soil constituents.

19. Wilcox L (2003) Electrical Conducctivity. In: Jaiswal P (ed.), Soil, plant and water analysis. Kalyani Publishing, New Delhi.

20. Jackson M (2003) Soil chemical analysis. In: Jaiswal P (ed.), Soil plant and water analysis. Kalyani Publishers, New Delhi.

21. Morocomp (2008) Design and application of innovarive composting unit for the effective treatment of sludge and other biodegradable organic waste in Morocco. Development of manuals for testing and analysis of compost. Morocomp, Morocco.

22. Mani A, Santhi R, Sellamuthu K (2007) A handbook of laboratory analysis
23. SAS (2002) SAS (r) proprietary software version 9:00 (TS MO). Cary, NC, USA

24. Augustin C, Rahman S (2010) Composting animal manure: A guide to the process and management of animal manure compost. The NDSU extension service.

25. Wu L, Ma L, Martinez G (2000) Comparison of methods for evaluating stability and maturity of biosolids compost. J Environ Qual 29: 424-429.

26. Varma V (2015) Composting of vegetable waste through different composting techniques. Doctorial Dissertation. Indian Institue of Technology, Guwahati, India.

27. Kassa H, Suliman H, Workayew $T$ (2011) Evaluation of composting process and qulity of compost from coffee by-product (coffee husk and pulp). Ethiopian Journal of Environmental Studies and Management 4: 8-13. 